\title{
ГОСУДАРСТВЕННО-ЧАСТНОЕ ПАРТНЕРСТВО КАК ИНСТРУМЕНТ ПРИВЛЕЧЕНИЯ ИНВЕСТИЦИЙ В МОДЕРНИЗАЦИЮ ЭКОНОМИКИ РЕГИОНА
}

\author{
(C) 2019 Рабаданова А.А. \\ кандидат экономических наук, научный сотрудник \\ Институт социально-экономических исследований ДНЦ РАН, Россия, Махачкала
}

В статье подчеркивается важная роль инвестиций в процессе реализации модернизации экономики региона. Эффективность модернизации экономики региона во многом определяется государственной политикой, а также мобилизацией и степенью рационального использования инвестиционных ресурсов. В России основным и реальным путем расширения инвестиционной деятельности и привлечения частных инвестиций может стать активное участие государства в софинансировании инвестиционных средств в экономику региона на основе государственно-частного партнерства.

Ключевые слова: регион, модернизация экономики, государственно-частное партнерство, инвестиции.

Решение проблемы модернизации экономики определяется множеством факторов, в первую очередь ресурсным обеспечением. В настоящее время, инвестиционная политика в регионах носит характер разнонаправленного процесса, обусловленного хроническим недостатком инвестиционных средств. Распределение инвестиций в силу их ограниченности не обеспечивает потребности приоритетных отраслей региона. В этой связи эффективность модернизации экономики региона в условиях дефицита регионального бюджета во многом определяется государственной политикой, а также мобилизацией и степенью рационального использования внутренних инвестиционных ресурсов.

«...Стратегия инвестиционного обеспечения перевода экономики на инновационный путь развития вместе с первоочередной поддержкой развития высокотехнологических секторов экономики, активизацией научноисследовательских и опытно-конструкторских разработок, стимулированием наращивания человеческого капитала и мобилизацией интеллектуальных ресурсов становится главным направлением структурных преобразований в стране. Именно этот вывод следует признать в качестве ответа па вопрос, куда необходимо направить ресурсы общества в первоочередном порядке» [2, с. 9-10].

Одним из важнейших приоритетов государственной политики развития и модернизации экономики является создание благоприятного инвестиционного климата и позитивного имиджа региона для привлечения в его экономику отечественного и иностранного капитала, современных передовых техники и технологий. В настоящее время в регионах в рамках реализации различных федеральных и региональных государственных программ проводится определенная работа по привлечению инвестиций для реализации инвестиционных проектов по развитию отдельных отраслей экономики и социальной сферы. Однако недостаток инвестиционных ресурсов и сложности получения кредитов продолжает оставаться основным фактором, ограничивающим дальнейший рост и модернизацию экономики региона.

В этой связи, на наш взгляд, встает необходимость проведения следующих важных масштабных мероприятий:

1) переориентация средств регионального и муниципальных бюджетов на инвестирование в основной капитал, развитие реальной экономики и структурную модернизацию;

2) модернизация кредитно-банковских организаций и учреждений, создание здесь здоровой конкурентной среды, направление их деятельности на кредитование и обеспечение инвестиционными средствами развитие реальной экономики;

3) повышение эффективности деятельности по привлечению частных инвестиций на реализацию перспективных инновационных проектов предприятий региона;

4) расширение кооперации и сотрудничества с другими регионами России, организация совместных производств; 
5) активное подключение предприятий региона в создаваемые отраслевые государственные и смешанные государственно-частные предприятия в России;

6) мобилизация всех ресурсов региона: производственных, трудовых, научнотехнических, финансовых и др. и их оптимальное использование.

В современных условиях важнейшим источником развития экономики и накопления капитала являются финансовые средства частных инвесторов. Однако в России реальным способом привлечения частных инвестиций и расширения инвестиционной деятельности может выступать активное государственное участие в осуществлении капитальных вложении в региональную экономику на основе государственно-частного партнерства. «Мировой опыт свидетельствует, что эффективным и привлекательным механизмом технологической модернизации и построения инновационной экономики является институт государственно-частного партнерства» [1, с. 18]. Мы согласны со Смотрицкой И.И., что новая экономическая стратегия невозможна без построения новой модели взаимоотношений государства, бизнеса и общества на основе партнерских контрактных отношений [6, с. 18]. Как показывает зарубежный опыт, переход во все больших масштабах к развитию государственночастного партнерства, расширение отраслей и сфер использования принципов партнерства обеспечивают существенный мультипликативный эффект [3, с. 7]. При этом необходимо мобилизовать потенциал государственно-частного партнерства на реализацию целей структурной перестройки, а для этого нужен четкий механизм привлечения инвестиций для реализации модернизации экономики региона.

Для исследования актуальности государственно-частного партнерства как инструмента привлечения инвестиций мы провели SWOT-анализ на примере Республики Дагестан и пришли к выводу, что проблемные регионы особенно нуждаются в консолидации усилий государства и бизнеса, чтобы совершить рывок в развитии экономики и выход на новый инновационный уровень (см. табл. 1).

Для проблемных регионов, таких как Республика Дагестан, наиболее актуальной задачей является обретение самодостаточности и осу-

Таблица 1. SWOT-анализ возможностей государственно-частного партнерства как инструмента привлечения инвестиций в экономики региона на примере Республики Дагестан

\begin{tabular}{|c|c|}
\hline Сильные стороны & Слабые стороны \\
\hline $\begin{array}{l}1 . \quad \text { Привлечение частных инвестиций в модерни- } \\
\text { зацию экономики может компенсировать существен- } \\
\text { ную ограниченность финансовых возможностей бюд- } \\
\text { жета республики в виду его высокой дотационности. } \\
2 . \quad \text { Именно гарантии государства в данном пар- } \\
\text { тнерстве могут нивелировать высокие предпринима- } \\
\text { тельские риски, существующие в республике. }\end{array}$ & $\begin{array}{l}\text { 1. Высокая коррупционная составляющая го- } \\
\text { сударственных структур региона, что отражается на } \\
\text { эффективности реализации мероприятий в сфере } \\
\text { государственно-частного партнерства. } \\
2 . \quad \text { Нехватка в республике крупных частных } \\
\text { инвесторов, обладающих возможностями участво- } \\
\text { вать в партнерстве в масштабных целях, таких } \\
\text { как модернизация и ускоренный рост экономики } \\
\text { региона. } \\
3 . \quad \text { Инвестиционная непривлекательность } \\
\text { региона вызывает сложности с привлечением } \\
\text { внешних частных инвестиций из-за рисков с их } \\
\text { возвратом. }\end{array}$ \\
\hline Возможности & Угрозы \\
\hline $\begin{array}{l}\text { 1. } \quad \text { Возможность более быстрыми темпами ре- } \\
\text { шить многие проблемы социально-экономического } \\
\text { развития в регионе и выйти на устойчивый рост, за } \\
\text { счет механизма ГЧП расширение стимулирующих фак- } \\
\text { торов привлечения частных и иностранных инвести- } \\
\text { ций путем налоговых льгот, использования льготного } \\
\text { кредитования, формирования инфраструктуры за счет } \\
\text { использования различных концессионных форм. } \\
2 . \quad \text { Возможность эффективной реализации } \\
\text { многих программных мероприятий по модернизации } \\
\text { экономики, так как именно на этом уровне происходит } \\
\text { торможение развития по разным причинам, но одной } \\
\text { из основных является недостаток финансовых ресур- } \\
\text { сов. }\end{array}$ & $\begin{array}{l}1 . \quad \text { Использование государственно-частного } \\
\text { партнерства в коррупционных схемах с целью на- } \\
\text { живы как с одной, так и, с другой стороны. } \\
2 . \quad \text { Нехватка кадрового потенциала и совре- } \\
\text { менных инновационных технологий и методов } \\
\text { управления как в государственной системе, так и в } \\
\text { регионе в целом. }\end{array}$ \\
\hline
\end{tabular}

Источник: составлено автором. 
ществление рывка в экономическом развитии. Осуществление такой масштабной цели, перевод экономики на новый инновационный уровень, и проведение комплексной модернизации требует вливания в экономику больших инвестиций. Бюджет республики существенно ограничен, большая его часть уходит на социальную сферу. Поэтому единственной реальной возможностью привлечения инвестиций для Республики Дагестан и других проблемных регионов мы видим государственно-частное партнерство.

Участие государственно-частного партнерства в финансировании капитальных вложении в развитие и структурную перестройку экономики, по нашему мнению, может осуществляться в следующих формах:

1) восстановление государственных и муниципальных унитарных предприятий (ГУП и МУП) и их техническое перевооружение за счет государственных и частных инвестиций путем софинансирования с дальнейшим преобразованием их в открытые акционерные общества (OAO) и распределением акций между инвесторами;

2) реконструкция путем софинансирования средств государства и частного инвестора ОАО с участием государства (пакет акций, доля в капитале) с соответствующим перераспределением пакета акций между инвесторами;

3) реконструкция частных предприятий (OAO, ЗАО, ООО) и их техническое перевооружение за счет государственных инвестиционных средств на условиях долевого участия государства в уставном капитале;

4) строительство новых предприятий за счет государственных инвестиций в основной капитал с преобразованием их в ОАО и свобод- ным распространением среди населения и юридических лиц акций этих предприятий;

5) в рамках реализации инвестиционных проектов строительство новых предприятий путем долевого финансирования за счет средств государства и частного инвестора с соответствующим распределением доли инвесторов в уставном капитале.

Мировой опыт свидетельствует о том, что одним из важных условий устойчивого развития и структурной модернизации современной экономики является масштабное развитие инновационного предпринимательства [4]. «Ключевым фактором эффективного функционирования инновационной системы России в рыночных условиях должно стать появление крупных компаний, заинтересованных в постоянном обновлении структуры выпуска продукции под давлением конкурентной среды» [3, С. 178].

Одним из перспективных направлений финансового обеспечения инновационной модернизации региональной экономики, на наш взгляд, является формирование специального государственно-частного регионального инвестиционного банка развития инновационной сферы, который будет аккумулировать средства из всех возможных источников и направлять их на реализацию приоритетных инновационных проектов [2].

Таким образом, государственное управление структурными преобразованиями экономики региона должно происходить в рамках сформированной четкой и стройной системы модернизации и эффективного механизма ее реализации за счет активного использования государственно-частного партнерства.

\section{Библиографический список}

1. Артамонов, Д.Ю. Институт государственно-частного партнерства в технологической модернизации экономики / Д.Ю. Артамонов, В.В. Медников, М.В. Новоселов // Региональные проблемы преобразования экономики. - 2014.- № 7.- С. 18-26.

2. Ганеев А.М. Особенности создания и функционирования институтов развития в Российской Федерации / А.М. Ганеев // Интеллект. Инновации. Инвестиции. 2016. № 8. С. 17-19.

3. Зельднер А.Г. Совершенствованию государственно-частного партнерства в России системный подход / А. Г. Зельднер // Экономические науки. 2013. № 98. С. 7-14.

4. Конищева Т.И. Тренд развития государственно-частного партнерства: опыт Евросоюза и США / Т.И. Конищева // Вопросы экономики и права. 2017. № 105. С. 49-54.

5. Смешко, О.Г. Структурная перестройка российской экономики: приоритеты и механизм регулирования / О.г. Смешко // Региональные проблемы преобразования экономики. - 2014. - № 7.- С. 6-17.

6. Смотрицкая И.И. Новая экономическая стратегия требует нового качества государственного управления / И.И. Смотрицкая // Вестник Института экономики Российской академии наук. 2017. № 5. С. 7-22.

7. Экономика России в условиях глобализации.-М.: Институт экономики РАН, 2006 г. 